\title{
TINGKAT PENGETAHUAN KESEHATAN GIGI PADA ORANG TUA ANAK USIA PRASEKOLAH
}

\author{
Yudha Rahina ${ }^{1,2}$, Chandra Iswari DIGAA ${ }^{1}$, Wirya Pratama IWA ${ }^{1,}$ Pradnyaparamita Duarsa ${ }^{3}$ \\ ${ }^{1}$ Dental Public Health Department, Mahasaraswati University Denpasar, Denpasar \\ ${ }^{2}$ Medical School doktoral student, Udayana University, Denpasar \\ ${ }^{3}$ Medical School, Udayana University, Denpasar \\ E-mail: yudharahina@gmail.com
}

\begin{abstract}
Oral health in children plays a very important role as it lays down the foundation for healthy permanent teeth. Parents' knowledge have impact on maintenance of young children's oral health. Purpose: To explore dental health knowledge of preschool children's parent, so can be designed the right education media for them. Explorative study was conducted to 129 mother of 4-6 year old from four kindergarten-schools was chosen by quote sample at the Saraswati Denpasar Foundation. Data were collected using questionnaires and structured interview. The parents have good knowledge of some aspect of oral health, but lacked knowledge about the oral hygiene maintain and transmission of dental infections. Their good knowledge is not supported by positive support behaviors of oral health for their children.All of mother using whats app (WA) social media. Preschoolers parents have good dental health knowledge, but it is necessary to increase awareness and behavior of oral health in their children considering their health of primary teeth is very important. WA can be used as an educational medium.
\end{abstract}

Keywords: oral health knowledge, parents, preschool children.

\section{PENDAHULUAN}

Pengetahuan ibu tentang kesehatan gigi merupakan faktor penting yang dapat berpengaruh kesehatan dan penyakit gigi anaknya ${ }^{1}$. Keluarga yang memiliki pengetahuan kebersihan mulut yang buruk memiliki kesulitan dalam menerapkan kebiasaan menjaga keadaan mulut yang sehat di rumah ${ }^{2}$. Pengetahuan dan pemahanan kesehatan gigi yang kurang pada orang tua akan menyebabkan perilaku pemeliharaan kesehatan gigi dan mulut pada anak yang kurang mendukung. Orang tua bertindak sebagai penjaga untuk perawatan kesehatan pada anak prasekolah. Oleh karena itu pengetahuan kesehatan gigi, nilai-nilai kepercayaan, sikap dan perilaku secara langsung maupun tidak langsung akan mempengaruhi kesehatan anak. Kurangnya kesadaran ini akan berdampak pada kesehatan mulut terhadap kesehatan umum selama perjalanan hidup anak tersebut ${ }^{3}$.

Usia prasekolah adalah usia kritis. Pada usia 4 tahun gigi susu telah tumbuh semua, sedangkan di usia 6 tahun merupakan awal terjadinya pergantian gigi tetap yang tidak akan tergantikan lagi hingga dewasa. Ada perbedaan struktur gigi antara gigi sulung dan gigi tetap. Email dan dentin gigi sulung lebih tipis, dan kontak proksimalnya lebih luas sehingga daerah proksimal lebih rentan terhadap karies gigi ${ }^{4}$. Dentin gigi sulung memiliki tubulus dengan diameter besar, yang merupakan jalan masuk bakteri lebih cepat hingga ke pulpa $^{5}$. Struktur gigi yang belum matang karena masih banyak mengandung ion karbonat menyebabkan struktur gigi mudah larut oleh asam ${ }^{6}$. Di masa pergantian gigi, dimana posisi gigi tidak rata juga akan menyebabkan gigi lebih susah untuk dibersihkan, sehingga lebih mudah terkena karies. Bila pada gigi susu tersebut mengalami karies maka risiko terkena karies pada gigi tetap akan lebih besar ${ }^{7}$. Anak prasekolah berisiko tinggi terkena karies gigi ${ }^{8}$ yang berdampak sangat buruk khususnya pada anak-anak?

Karies gigi di usia prasekolah juga berdampak pada pertumbuhan dan perkembangan anak. Karies gigi menyebabkan gangguan tumbuh kembang anak, dan terbukti mempengaruhi kualitas hidupnya ${ }^{10}$. Menurut Bloom dalam 4 tahun pertama usia anak, perkembangan kognitifnya mencapai sekitar 50\%, mencapai 80\% dalam kurun waktu 8 tahun, dan $100 \%$ setelah 18 tahun $^{11}$. Bila karies terjadi pada usia anak-anak, maka perkembangan kognitif anak akan terganggu.

Usia prasekolah pada anak juga merupakan saat yang kritis terbentuknya keterampilan, sikap, kebiasaan buruk dan faktor risiko terjadinya penyakit mulut. Di masa ini anak diperkenalkan pada awal pemeriksaan klinis yang komprehensif, karena mereka adalah pembelajar yang cepat dan ingin memperoleh keterampilan baru, yang juga berisiko dengan masalah kesehatan mulut ${ }^{12}$.

Kesehatan gigi yang buruk di awal masa anakanak merupakan salah satu kondisi yang serius. Data Riskesdas $2018^{13}$ menunjukkan bahwa anak usia 5-6 tahun $92,7 \%$ menderita karies, dengan dmf-t 8,43. Data tersebut tidak jauh berbeda dengan hasil penelitian di Bali pada kelompok umur 4-6 tahun yaitu prevalensi $91,25 \%$ dengan rata-rata karies 7,5914. Menurut WHO anak usia 5 tahun dengan angka pengalaman karies $\geq 6$ termasuk dalam kategori Severe Early Childhood Caries $(\mathrm{S}-\mathrm{ECC})^{15}$.

Penelitian ini bertujuan untuk mengetahui tingkat pengetahuan kesehatan gigi pada orang tua anak usia prasekolah sehingga bisa dirancang media pendidikan yang tepat bagi mereka.

\section{BAHAN DAN METODE}

Penelitian ini merupakan penelitian exploratif yang dilakukan pada 129 ibu anak prasekolah di 
lingkungan TK saraswati 1, 2, 3 dan 4 Denpasar, yang dipilih secara kuota sampling. Instrumen yang digunakan untuk mengukur tingkat pengetahuan adalah wawancara tersruktur dan kuesioner. Dalam wawancara selain identitas diri responden, juga ditanyakan kebiasaan makan dan minum yang diberikan untuk anak, kebiasaan atau perilaku yang berhubungan dengan kesehatan gigi anak, serta mitos mengenai kesehatan gigi yang dipercaya oleh orang tua mengenai kesehatan gigi pada anak. Sebelumnya orang tua diminta untuk mengisi informed consent lebih dahulu.

Kuesioner tersebut berisi tentang: pengetahuan kebiasaan kesehatan gigi (8 soal: q1-8), pengetahuan nutrisi gigi (11 kuesioner: q9-19), pengetahuan fungsi gigi (5 soal: q20-24), pengetahuan kebersihan gigi dan mulut (16 soal: q25-40), Pengetahuan perawatan/pemeriksaan gigi (7 soal: q41-47), pengetahuan penularan infeksi gigi (5 soal: q48-52), Pengetahuan dampak kesehatan gigi (7 soal: q53-60). Jadi jumlah keseluruhan dari kuesioner adalah 60 soal yang diberi kode q1, q2, q3 hingga q60. Uji validitas dan reliabilitas dilakukan pada kuesioner-kuesioner tersebut. Hasil uji validitas menunjukkan bahwa 9 kuesioner tidak valid. Kuesioner yang tidak valid diperbaiki dan dipergunakan lagi. Seluruh kuesioner dinyatakan reliabel.

\section{HASIL}

Analisis deskriptif menampilkan karakteristik responden yang meliputi usia ibu, tingkat pendidikan, pekerjaan, media sosial yang digunakan usia anak dan jenis kelamin anak. Selain itu juga frekuensi dan distribusi jenis makanan dan minuman yang biasa diberilkan, perilaku terhadap perawatan kesehatan gigi anak serta nilai-nilai yang dipercaya tentang kesehatan gigi anak. Profil responden penelitian ditampilkan pada Tabel 1.

\section{Karakteristik Responden}

\begin{tabular}{cccccccc}
\multicolumn{8}{c}{ Tabel 1. Profil responden } \\
\hline \multicolumn{2}{c}{$\begin{array}{c}\text { Usia } \\
\text { (tahun) }\end{array}$} & \multicolumn{7}{c}{ Tingkat pendidikan } & & Pekerjaan \\
\hline Range & Rerata & $\begin{array}{c}\text { D } \\
(\%)\end{array}$ & $\begin{array}{c}\text { M } \\
(\%)\end{array}$ & T (\%) & $\begin{array}{c}\text { IRT } \\
(\%)\end{array}$ & K (\%) & W \\
& & & & & & & $(\%)$ \\
\hline $26-41$ & 33,2 & 0 & 11,88 & 88,12 & 52,54 & 20,34 & 27,12
\end{tabular}

Ket: D (Dasar), M (Menengah), T (Tinggi), IRT (Ibu Rumah Tangga), K (Karyawan), W (Wiraswasta)

Rata-rata usia Ibu adalah 33 tahun. Sebagian besar Ibu memiliki tingkat pendidikan yang tinggi dan tidak ada yang berpendidikan dasar. Lebih dari setengah responden dalam penelitian ini adalah Ibu Rumah Tangga, selebihnya mereka berwiraswasta dan bekerja sebagai karyawan, baik sebagai pegawai negeri ataupun swasta.

Tabel 2. Media sosial yang digunakan Media sosial

\begin{tabular}{lcccc}
\hline $\begin{array}{l}\text { WA } \\
(\%)\end{array}$ & Ig & Line & FB & T \\
$(\%)$ & $(\%)$ & $(\%)$ & $(\%)$ \\
\hline 100 & 59,7 & 10,85 & 52,71 & 2,32 \\
\hline
\end{tabular}

Ket: WA (WhatsApp), Ig (Instagram), FB (Face Book), T (Telegram)

Dalam kesehariannya responden selalu memanfaatkan media sosial dalam berkomunikasi. Media sosial yang banyak digunakan adalah WA, yang digunakan oleh semua responden, disusul dengan IG, FB, Line dan Telegram. Telegram adalah media sosial yang tidak popular di kalangan responden.

Tabel 3. Profil anak

\begin{tabular}{cccc}
\hline \multicolumn{2}{c}{$\begin{array}{c}\text { Usia anak } \\
\text { (tahun) }\end{array}$} & \multicolumn{2}{c}{ Jenis Kelamin } \\
\hline Range & Rerata & Laki-laki & Perempuan \\
\hline $4-6$ & 4,62 & $83(64,34 \%)$ & $46(35,66 \%)$ \\
\hline
\end{tabular}

Ibu-ibu yang menjadi responden dalam penelitian ini merupakan orang tua murid Taman Kanak-kanak. Anak-anak tersebut berumur antara 4 hingga 6 tahun. Jumlah anak laki-laki lebih dominan bila dibandingkan dengan anak perempuan.

\section{Frekuensi dan distribusi makanan dan minuman yang diberikan pada anak, serta perilaku menyikat gigi}

Sebagian besar anak-anak sangat jarang makan makanan cepat saji. Mereka yang sering mendapatkan buah dan sayur dalam kesehariannya walaupun kurang dari 50\% responden. Sebagian besar responden mengaku sering memberikan camilan kepada anak-anaknya. Camilan yang banyak digemari adalah coklat, kue, permen dan es krim.

Tabel 4. Distribusi makanan yang biasa berikan pada anak

\begin{tabular}{|c|c|c|c|c|c|c|c|}
\hline \multirow[t]{2}{*}{ Kategori } & \multicolumn{2}{|c|}{$\begin{array}{l}\text { Makanan } \\
\text { cepat saji }\end{array}$} & \multicolumn{2}{|c|}{ Buah } & \multicolumn{2}{|c|}{ Sayur } & Camilan \\
\hline & $\Sigma$ & $\%$ & $\Sigma$ & $\%$ & $\Sigma$ & $\%$ & $\Sigma$ \\
\hline Tidak & \multicolumn{2}{|c|}{$13(10,1 \%)$} & \multicolumn{2}{|c|}{$20(15,5 \%)$} & \multicolumn{2}{|c|}{$20(15,5 \%)$} & $3(2,3 \%)$ \\
\hline $\begin{array}{l}\text { Sangat } \\
\text { jarang }\end{array}$ & \multicolumn{2}{|c|}{$78(60,5 \%)$} & \multicolumn{2}{|c|}{$21(16,3 \%)$} & \multicolumn{2}{|c|}{$27(20,9 \%)$} & $17(13,2 \%)$ \\
\hline Jarang & \multicolumn{2}{|c|}{$34(26,3 \%)$} & $38(2$ & $, 5 \%)$ & \multicolumn{2}{|c|}{$24(18,6 \%)$} & $44(34,1 \%)$ \\
\hline ering & \multicolumn{2}{|c|}{$4(3,1 \%)$} & $50(3$ & ,7\%) & \multicolumn{2}{|c|}{$58(45 \%)$} & $65(50,4 \%)$ \\
\hline & \multicolumn{2}{|c|}{$129(100 \%)$} & & $00 \%)$ & & $00 \%)$ & $129(100 \%)$ \\
\hline
\end{tabular}

\footnotetext{
Ket: Tidak (0), Sangat jarang ( $\leq 1 x$ perbulan), Jarang ( $>1 x$ perbulan dan $\leq 1 \mathrm{x}$ perminggu), Sering ( $>1 \mathrm{x}$ perminggu)
}

Jumlah anak yang sering minum minuman kemasan lebih dari setengah responden, minuman kemasan yang banyak dikonsumsi adalah susu, teh manis, minuman berkarbonasi dan minuman rasa buah. Kebiasaan minum susu dengan botol banyak dilakukan oleh anak-anak. Kebiasaan ini dilakukan terutama di saat menjelang tidur.

Tabel 5. Frekuensi pemberian minuman kemasan

\begin{tabular}{lccccc}
\hline Kategori & tidak & $\begin{array}{l}\text { Sangat } \\
\text { jarang }\end{array}$ & Jarang & Sering & Total \\
\hline Jumlah & 30 & 7 & 23 & 69 & 129 \\
\hline Persentase & 23,25 & 5,43 & 17,83 & 53,49 & 100 \\
\hline $\begin{array}{l}\text { Ket: Tidak (0), Sangat jarang }(\leq 1 \text { 1 perbulan), Jarang }(>1 \text { x perbulan } \\
\text { dan } \leq \text { 1x perminggu), Sering }(>1 \times \text { perminggu })\end{array}$
\end{tabular}


Tabel 6. Pemberian susu botol

\begin{tabular}{lccc}
\hline Kategori & Tidak & Ya & Total \\
\hline Jumlah & 70 & 59 & 129 \\
\hline Persentase $(\%)$ & 52,26 & 47,74 & 100 \\
\hline $\begin{array}{l}\text { Ket: Tidak (0), Sangat jarang }(\leq 1 \text { 1x perbulan), Jarang }(>1 \text { x perbulan } \\
\text { dan } \leq \text { 1x perminggu), Sering ( }>\text { 1x perminggu })\end{array}$
\end{tabular}

Aktivitas menyikat gigi juga dilakukan dalam keseharian responden dan anaknya di rumah. Diantara 129 responden, hanya 20 orang yang membantu anak menyikat gigi, sebagian besar membiarkan anak menyikat gigi sendiri, sedangkan 5 responden membiarkan anak tidak menyikat gigi. Waktu menyikat gigi yang paling disukai adalah waktu mandi.

Tabel 7. Kebiasaan anak menyikat gigi

\begin{tabular}{|c|c|c|c|c|c|c|c|c|}
\hline \multirow[t]{3}{*}{ Kategori } & \multicolumn{4}{|c|}{ Menyikat gigi } & \multicolumn{4}{|c|}{ Waktu } \\
\hline & $\mathrm{T}$ & $\mathrm{S}$ & $\mathrm{Pi}$ & Dbi & $\mathrm{Bt}$ & M & Ss & St \\
\hline & & & & & & & & $\mathrm{m}$ \\
\hline Jumlah & 5 & 91 & 13 & 20 & 13 & 122 & 7 & 39 \\
\hline $\begin{array}{l}\text { Persentase } \\
(\%)\end{array}$ & $\overline{3,9}$ & 70,5 & 10 & 15,5 & 10 & 94,6 & 5,4 & 30,2 \\
\hline $\begin{array}{ll}\text { Ket: } & \mathrm{T}(\mathrm{T} \\
\mathrm{Bt} & \\
& \text { (Ban } \\
& \text { tidur }\end{array}$ & & M & $\mathrm{Pi}$ & & $\mathrm{Sc}$ & Dbi & & elum \\
\hline
\end{tabular}

\section{Perawatan gigi anak}

Sepertiga dari total responden mengetahui bahwa anaknya pernah mengeluhkan sakit gigi. Sisanya adalah anak tidak pernah mengeluhkan sakit gigi. Terdapat responden yang bersikap membiarkan anak sakit tanpa pengobatan, karena beranggapan sakit gigi adalah hal yang biasa terjadi pada anak

Tabel 8. Keluhan sakit gigi anak dan sikap responden

\begin{tabular}{llllcc}
\hline Kategori & \multicolumn{4}{l}{ Keluhan sakit gigi } & \multicolumn{3}{l}{ Sikap responden } \\
\cline { 2 - 6 } & Tidak & Ya & TP & PS & $\begin{array}{l}\text { Dokter } \\
\text { gigi }\end{array}$ \\
\hline Jumlah & 87 & 42 & 27 & 47 & 55 \\
\hline $\begin{array}{l}\text { Persentase } \\
(\%)\end{array}$ & 67,44 & 32,56 & 20,93 & 36,43 & 42,64 \\
\hline Ket: TP (Tanpa Pengobatan), PS (Pengobatan sendiri) &
\end{tabular}

Dari 129 responden ternyata sebagian besar tidak pernah memiliki pengalaman dengan dokter gigi. Hanya sebagian kecil responden yang pernah membawa anak untuk berobat dan kontrol ke dokter gigi.

Tabel 9. Pengalaman perawatan ke dokter gigi

\begin{tabular}{lccccc}
\hline Kategori & Tidak & \multicolumn{4}{c}{ Ya } \\
\cline { 3 - 6 } & & Tumpat & Cabut & Obat & Kontrol \\
\hline Jumlah & 113 & 3 & 4 & 5 & 4 \\
\hline $\begin{array}{l}\text { Persentase } \\
(\%)\end{array}$ & 87,6 & 2,32 & 3,10 & 3,88 & 3,10 \\
\hline
\end{tabular}

\section{Nilai-Nilai Kepercayaan}

Seluruh responden percaya bahwa gigi anakanak perlu dirawat. Lebih dari setengah responden percaya bahwa pemakaikan susu botol akan memberikan masalah pada kesehatan gigi anaknya.
Namun ada yang mempercayai bahwa kebiasaan minum susu botol pada anak tidak akan menimbulkan masalah. Sebagian kecil responden masih mempercayai adanya ulat di dalam gigi yang berlubang dan terjadi demam pada anak saat gigi mereka mau tumbuh.

Tabel 10. Nilai-nilai kepercayaan responden terhadap kesehatan gigi anak

\begin{tabular}{|c|c|c|c|c|c|c|c|c|}
\hline \multirow[t]{2}{*}{ Kategori } & \multicolumn{2}{|c|}{$\begin{array}{l}\text { Perlunya } \\
\text { perawatan } \\
\text { gigi anak }\end{array}$} & \multicolumn{2}{|c|}{$\begin{array}{l}\text { Masalah } \\
\text { pemakaian } \\
\text { susu botol }\end{array}$} & \multicolumn{2}{|c|}{$\begin{array}{l}\text { Ulat } \\
\text { dalam } \\
\text { lubang } \\
\text { gigi }\end{array}$} & \multicolumn{2}{|c|}{$\begin{array}{l}\text { Demam } \\
\text { saat } \\
\text { tumbuh } \\
\text { gigi }\end{array}$} \\
\hline & $\mathrm{T}$ & $\mathrm{Ya}$ & $\mathrm{T}$ & $\mathrm{Ya}$ & $\mathrm{T}$ & $\mathrm{Ya}$ & $\mathrm{T}$ & $\mathrm{Ya}$ \\
\hline Jumlah & 0 & 129 & 60 & 69 & 98 & 31 & 86 & 43 \\
\hline $\begin{array}{l}\text { Persentase } \\
(\%)\end{array}$ & 0 & 100 & 46,5 & 53,5 & 76 & 24 & 67,7 & 33.3 \\
\hline
\end{tabular}

\section{Distribusi variabel pengetahuan tentang kesehatan gigi pada responden}

Data tingkat pengetahuan kesehatan gigi pada responden menunjukkan bahwa tidak ada yang memiliki tingkat pengetahuan kesehatan gigi yang kurang. Hampir seluruh responden memiliki tingkat pengetahuan kesehatan gigi yang baik. Namun walaupun mereka memiliki pengetahuan dengan kategori baik, ada beberapa kuesioner yang dijawab tidak tahu dan salah oleh responden. Sebagian besar responden menjawab salah dan tidak tahu terhadap pertanyaan mengenai pengetahuan tentang menjaga kebersihan gigi dan penularan infeksi gigi.

Tabel 11. Tingkat pengetahuan kesehatan gigi

\begin{tabular}{lccc}
\hline Kategori & Kurang & Sedang & Baik \\
\hline Jumlah & 0 & 2 & 127 \\
\hline Persentase (\%) & 0 & 1,55 & 98,45 \\
\hline
\end{tabular}

Tabel 12. Kategori jawaban responden terhadap kuesionerpengetahuan kesehatn gigi.

\begin{tabular}{llr}
\hline Kategori & $\begin{array}{l}\text { Persentase } \\
\text { jawaban } \\
\text { dalam seluruh } \\
\text { kuesioner }\end{array}$ & $\begin{array}{r}\text { Jumlah } \\
\text { (persentase) }\end{array}$ \\
\hline Betul & & $4(6,7 \%)$ \\
\hline $\begin{array}{l}\text { Salah /tidak } \\
\text { tahu }\end{array}$ & $<25 \%$ & $35(58,3 \%)$ \\
\cline { 2 - 3 } & $26 \%-49 \%$ & 13 \\
& $\geq 50 \%$ & $81,7 \%)$ \\
\hline
\end{tabular}

\section{Analisis uji komparasi}

Uji komparasi dilakukan untuk mengetahui apakah ada perpedaan tingkat pengetahuan pada ke empat kelompok responden, yaitu TK 1, 2, 3, dan 4. Hasil menunjukkan bahwa tidak ada perbedaan tingkat pengetahuan antara ke empat kelompok responden tersebut $(\mathrm{p}>0,05)$. 
Tabel 13. Uji anova tingkat pengetahuan responden di TK $1,2,3$, dan 4

\begin{tabular}{lrrrr}
\hline Pengetahuan & $\mathrm{df}$ & $\begin{array}{r}\text { Mean } \\
\text { Square }\end{array}$ & F & Sig. \\
\hline Between Groups & 3 & 138.490 & 1.024 & .384 \\
\hline Within Groups & 125 & 135.194 & & \\
\hline Total & 128 & & & \\
\hline
\end{tabular}

\section{PEMBAHASAN}

Responden adalah ibu-ibu muda dengan rata-rata umur 33,2 tahun. Mereka memiliki tingkat pendidikan menegah dan tinggi dan sebagian besar adalah ibu rumah tangga. Mereka merupakan pengguna aktif sosial media. Sosial media yang paling populer dikalangan mereka adalah WA yang digunakan oleh seluruh responden.

Sebagian besar responden memiliki tingkat pendidikan yang tinggi. Tingkat Pendidikan ini berhubungan dengan tingkat pengetahuan ${ }^{16}$. Orang dengan pendidikan yang tinggi akan memiliki pengetahuan yang lebih baik $^{17}$ dan sikap yang baik tentang kesehatan sehingga akan mempengaruhi perilakunya untuk hidup sehat. Lemos dkk. ${ }^{18}$ dalam penelitiannya menunjukkan bahwa orang tua dengan tingkat pendidikan menegah (setingkat SMA) beranggapan bahwa promosi kesehatan gigi penting dilakukan, agar anak mengenal program kesehatan gigi dan mulut, dan mengadopsi kebiasaan sehat sedini mungkin, disamping anak akan patuh pada saran orang tuanya. Semakin tinggi tingkat pendidikan orang tua, akan mempengaruhi tingkat pengetahuannya, namun sebagian besar orang tua masih memiliki tingkat pengetahuan yang buruk mengenai pertumbuhan gigi anak $^{19}$. Berbeda dengan hasil studi ini, bahwa ibu anak prasekolah memiliki tingkat pengetahuan yang baik. Tingkat pengetahuan mereka pada ke-empat TK ini tidak menunjukkan perbedaan yang bermakna. Pengetahuan, kebiasaan, sikap dan self efficacy baik pada guru dan orang tua sering dihubungkan dengan karies gigi, kebersihan mulut yang buruk, dan status nutrisi pada anak ${ }^{20-22}$.

Merupakan hal yang bagus bagi anak-anak karena mereka sangat jarang diberikan makanan cepat saji oleh orang tua mereka, mereka sering mendapat makanan sehat seperti buah dan sayur. Makan sayuran dan buah-buahan yang berserat dan berair yang akan bersifat membersihkan dan merangsang sekresi saliva ${ }^{23}$. Tetapi hal yang buruknya adalah mereka sering mendapatkan camilan yang kariogenik, apalagi seperti permen, kue, coklat, ice cream dan minuman kemasan yang manis. Anak-anak yang makanan dan minuman manis menjelang tidur di malam hari, seperti susu botol dan camilan memiliki risiko karies lebih tinggi ${ }^{24}$. Esan $\mathrm{dkk}^{25}$ memperbolehkan snack manis hanya 1 kali sehari. Orang tua tahu bahwa makanan dan minuman manis dapat menyebabkan gigi berlubang ${ }^{17}$. Berkurangnya mengkonsumsi makanan yang rendah gula dan frekuensi camilan dalam satu tahun berhubungan kuat dengan karies pada anak-anak ${ }^{26}$. Oleh karena itu pemilihan pola makan orang tua sangat penting untuk perilaku diet jangka panjang pada anak- anak, dan ini ditentukan oleh sikap dan pengetahuan orang tua.

Salah satu faktor yang dapat mempengaruhi erupsi gigi permanen adalah asupan gizi dan status gizi pada anak ${ }^{27}$. Alvarez ${ }^{28}$ mengamati hubungan malnutrisi atau status gizi buruk dengan karies gigi didapatkan hasil, bahwa malnutrisi pada anak tidak hanya dapat menghambat erupsi gigi dan mempengaruhi peningkatan karies gigi, tetapi juga terkait dengan tingginya angka kehilangan gigi pada gigi susu maupun gigi permanen. Nutrisi sebagai faktor pertumbuhan dapat mempengaruhi erupsi dan proses kalsifikasi gigi.

Telah diketahui bahwa dengan menjaga kesehatan umum dan gigi yang baik akan dapat mencegah terjadinya penyakit mulut. Perilaku kebersihan mulut seperti menjaga asupan makanan, kontrol plak dan penggunaan pasta berfluoride dapat mencegah penyakit gigi, walaupun perilaku ini lebih banyak dipengaruhi oleh faktor sosial ${ }^{29}$. Jumlah bakteri plak menurun setelah menyikat gigi ${ }^{30}$. Menyikat gigi secara teratur setidaknya dua kali sehari dengan menggunakan pasta gigi yang mengandung fluoride untuk mencegah karies pada anak-anak prasekolah dapat mencegah terjadinya karies gigi ${ }^{31}$. Menjaga kebersihan mulut dengan kontrol plak yang efektif adalah dengan menyikat gigi sehari 2 kali yaitu diwaktu pagi dan malam ${ }^{29}$. Pagi setelah sarapan dan malam menjelang tidur. Sebagian besar ibu tahu bahwa membersihkan gigi setiap hari itu diperlukan, namun menyikat gigi sehari 2 kali atau lebih perhari belum menjadi kebiasaan ${ }^{12}$. Dalam studi ini sebagian besar anak menyikat gigi pada waktu mandi karena begitu pula yang dilakukan oleh orang tuanya. Pengetahuan, nilai-nilai kepercayaan dan sikap orang tua berpengaruh terhadap perilaku menyikat gigi anak-anaknya ${ }^{32}$. Kebiasaan perilaku kesehatan gigi pada masa anak-anak biasanya diadopsi dari orang tuanya terutama $i b u^{33}$.

Sebagian besar anak menyikat giginya sendiri bahkan tanpa pengawasan orang tua. Bahkan diketahui ada 5 anak yang tidak menyikat gigi. Ironisnya adalah bahwa sebagian besar pekerjaan ibu-ibu anak prasekolah dalam studi ini adalah ibu rumah tangga, yang justru mempunyai lebih banyak waktu di rumah untuk memperhatikan dan membantu perilaku kesehatan anak yang positif. Orang tua diharapkan dapat berperan aktif dalam memelihara kesehatan gigi dan mencegah penyakit gigi pada anaknya, karena anak di usia prasekolah ini masih memerlukan dukungan orang tua untuk menjaga kesehatan giginya secara mandiri ${ }^{34}$. Bantuan orang tua saat menyikat gigi sehari-hari memberi dampak yang lebih baik untuk kesehatan gigi anak $^{35}$. Bahkan anak sebaiknya menyikat gigi dibawah pengawasan orang tuanya sampai usia 9 tahun, dan orang tua harus memeriksa kegiatan anak waktu menyikat gigi serta mengetahui perkembangan cara menyikat giginya hingga usia 14 tahun $^{36}$. Walaupun pengetahuan tentang kesehatan gigi mereka adalah baik, dan mereka sadar bahwa menyikat gigi dapat pencegah terjadinya gigi karies dan penyakit gusi, namun ternyata mereka dalam praktik kesehariannya kurang peduli. Beberapa studi menggarisbawahi bahwa karies pada 
anak akan terus berkembang walaupun kesadaran akan masalah tersebut lebih baik. Sikap dan perilaku orang tua dan faktor sosio-ekonomi berdampak pada awal perkembangan karies ${ }^{35}$. Sikap kurang peduli ini menunjukkan bahwa kesehatan gigi belum menjadi prioritas bagi mereka.

Walaupun diketahui ada 42 anak (32\%) yang mengeluhkan sakit gigi, namun terdapat 55 orang tua (42\%) yang bersikap akan membawa anak ke dokter gigi untuk mendapatkan pengobatan, sedangkan sisanya diobatin sendiri dirumah dengan penghilang rasa sakit dan berkumur air garam, dan bahkan ada yang dibiarkan saja tanpa tindakan apapun. Orang tua meyakini bahwa perawatan kesehatan gigi pada anak-anak itu dipenting, sesuai dengan penelitian Singhal $\mathrm{dkk}^{12}$, namun kepedulian terhadap perawatan gigi yang karies masih rendah. Dalam penelitiannya Khaduri ${ }^{17}$ diketahui bahwa orang tua akan membawa anak untuk mengunjungi dokter gigi bila ada masalah saja. Dalam studi ini ada ibu yang mengaku terpaksa membawa anaknya ke dokter gigi karena pipiya sudah bengkak. Keadaan ini menunjukkan perlunya pengertian yang lebih dalam terhadap nilai-nilai yang dipercaya dalam bidang kesehatan dengan praktik nyata dengan menghargai kebutuhan perawatan kesehatan gigi pada anakanaknya $^{17}$. Beberapa orang tua beranggapan bahwa gigi susu akan digantikan oleh gigi permanen yang lebih kuat, dan ada yang beranggapan 'kasihan anak masih kecil, kalau anak di bawa ke dokter, nanti trauma'.

Memeriksakan kesehatan gigi anak ternyata belum dianggap sebagai kebutuhan bagi orang tua. Sebagian besar belum pernah punya pengalaman ke dokter gigi. Ternyata ada $12,4 \%$ anak yang pernah menjalani perawatan gigi di dokter gigi. Perawatan tersebut meliputi perawatan tambal gigi, cabut gigi, pemeriksaan untuk mendapatkan obat dan kontrol. Kunjungan rutin ke dokter gigi untuk perawatan kesehatan gigi dan mulut belum menjadi norma pada anak-anak ${ }^{37}$. Gigi dibiarkan berlubang dan tidak dirawat. Keputusan orang tua dipengaruhi oleh sikap yang akan terefleksi pada kesehatan gigi anaknya ${ }^{32}$.

Sesuai penelitian Khaduri dkk. ${ }^{17}$ dan Mahat \& Bowen $^{38}$, hasil studi ini juga menunjukkan bahwa orang tua menganggap perlu untuk melakukan pemeriksaan gigi anak secara teratur, namun hanya $16 \%$ saja yang melakukannya, karena mereka hanya akan mengunjungi dokter gigi bila ada masalah saja. Sesuai pendapat Edelstein $^{39}$, orang tua biasanya menunggu sampai gigi yang karies sakit, baru mengunjungi dokter gigi. Pengetahuan kesehatan gigi dan self efficacy pada ibu anak prasekolah akan berpengaruh juga pada kebiasaaan kesehatan gigi dalam kesehariannya di rumah ${ }^{40}$. Namun berbeda dengan studi ini bahwa pengetahuan ibu yang baik mengenai kesehatan gigi ternyata kurang mendukung perilaku positif terhadap kesehatan gigi untuk anak-anaknya.

Hampir setengah anak-anak masih mengkonsumsi susu botol $(47,7 \%)$, terutama di saat menjelang tidur. Pemberian susu botol dan makanan kariogenik di waktu malam merupakan faktor yang mempengaruhi karies Gigi ${ }^{18}$. Belum semua orang tua mengetahui bahwa minum susu dengan botol dapat menyebabkan karies. Terdapat $46,5 \%$ orang tua yang masih beranggapan bahwa minum susu dengan botol tidak akan memberikan dampak yang buruk bagi kesehatan gigi anaknya. Perhatian orang tua akan kesehatan gigi anak yang kurang ini bisa menjadi faktor penting terjadinya karies botol ${ }^{41}$. Perlu ditingkatkan pengetahuan pada orang orang tua bahwa cara anak minum susu dengan botol dapat menyebabkan karies gigi, sehingga perlu dibangun kesadaran untuk mencegah efek buruk tersebut, yaitu tidak memberikan anak minum susu dengan botol terutama di waktu menjelang tidur $^{17}$.

Suatu kepercayaan kuno yang dipercaya pada masyarakat lokal adalah bahwa di dalam gigi berlubang terdapat ulat-ulat kecil. Nilai-nilai masyarakat tersebut masih dipercaya oleh $24 \%$ orang tua, sedangkan sisanya menyatakan bahwa hal tersebut hanya merupakan mitos.

Orang tua $(67,7 \%)$ dalam studi ini mempercayai bahwa saat tumbuh gigi, anak akan disertai demam. Hal yang sama dipercayai juga oleh orang tua di Makassar bahwa pada saat tumbuh gigi anak akan mengalami demam dan juga diare ${ }^{19}$. Pada saat gigi mau tumbuh, terjadi peradangan pada gusi. Jika peradangan tersebut cukup serius, maka mungkin anak akan mengalami demam. Akan tetapi, demam yang disebabkan oleh peradangan gusi karena gigi mau tumbuh biasanya tidak begitu tinggi.

Hasil penelitian menunjukkan bahwa sebagian besar responden menjawab salah dan tidak tahu terhadap pertanyaan mengenai pengetahuan tentang menjaga kebersihan gigi dan penularan infeksi gigi. Studi dari berbagai negara menunjukkan hal yang sama yaitu para orang tua memiliki keterbatasan tentang penyebab dan pencegahan penyakit yang biasa terjadi dalam rongga mulut ${ }^{42}$.

Meningkatnya pengetahuan, kesadaran dan perubahan perilaku pada orang tua secara tidak langsung merupakan unsur penting dalam pencegahan penyakit gigi pada anak prasekolah ${ }^{31}$. Pengetahuan, nilai-nilai kepercayaan, sikap dan perilaku kesehatan gigi secara langsung ataupun tidak langsung menpengaruhi kesehatan mulut di masa awal anak-anak oleh karena itu orang tua dan pengasuh dapat berperan sebagai penjaga untuk pencegahan penyakit gigi anak pra sekolah ${ }^{43}$.

Masalah kesehatan gigi khususnya kesehatan gigi anak belum menjadi prioritas utama, hal ini disebabkan oleh kurangnya sosialisasi, media, juga pemahaman tentang pentingnya menjaga kesehatan gigi anak yang berpengaruh pada masa pertumbuhan dan perkembangan anak ${ }^{44}$. Selain pengetahuan dan sikap, kesadaran orang tua juga berpengaruh terhadap kesehatan gigi anak ${ }^{45}$. Pengetahuan dan sikap orang tua memberi dampak pada perawatan kesehatan gigi anakanaknya. Sikap yang positif akan memberi kesehatan gigi yang lebih baik pada anak-anaknya ${ }^{17}$. Sikap, pengetahuan, dan kepercayaan orang tua akan memengaruhi pilihan yang dibuat orang tua bagi anakanak mereka tentang perilaku yang mereka contohkan kepada anak-anak mereka, yang berkembang di masa kecil mereka ${ }^{24}$. Keberhasilan pencegahan karies gigi pada anak prasekolah akan lebih tercapai jika 
pendidikan diberikan kepada orang tuanya ${ }^{46}$. Penting bagi ibu dapat mendeteksi dan mencegah karies gigi serta masalah-masalah yang berhubungan dengan kesehatan gigi pada anak ${ }^{47}$. Selain sebagai model, ibu juga membuat keputusan bagi anak-anaknya. Kebiasaan yang dilakukan di masa kanak-kanak adalah diadopsi dari ibunya, termasuk perilaku yang baru ${ }^{12}$.

\section{SIMPULAN}

Orang tua anak prasekolah memiliki pengetahuan kesehatan gigi yang baik, namun perlu ditingkatkan kesadaran dan perilaku kesehatan gigi pada anaknya mengingat kesehatan gigi susu itu sangat penting. Oleh karena itu perlu dilakukan edukasi untuk orang tua untuk meningkatkan pengetahuan dan kesadaran akan kesehatan gigi anak yang dapat menunjang perilaku kesehatan gigi yang positif. Pemakaian sosial media terutama WA yang akrab dan digunakan oleh seluruh responden dapat dimanfaatkan sebagai media pendidikan kesehatan gigi.

\section{UCAPAN TERIMA KASIH}

Ucapan terimakasih kami sampaikan kepada Kepala sekolah, para guru dan murid TK Saraswati 2 dan Saraswati 4 yang telah bersedia menjadi sampel. Juga kepada mahasiswa program profesi yang sudah membantu terlaksananya penelitian ini.

\section{DAFTAR PUSTAKA}

1. Jayanti CD. Hubungan tingkat pengetahuan ibu tentang karies gigi dengan kejadian karies gigi pada anak TK Aisyiyah Kateguhanan Sawit Boyolali. Surakarta: Fakultas Ilmu Kesehatan Univ. Muhamadiyyah, 2012

2. Aljafari A. Rice C. Gallagher JE. Hosey MT. An oral health education video game for high caries risk children : study protocol for a randomized controlled trial, BMC, 2015; 16 (237) :1-10.

3. Horowitz AM. Kleinman DV. Oral health literacy: a pathway to reducing oral health disparities in Maryland. Journal of Public Health Dentistry. 2012; 72(S1): S26-S30.

4. Ramanalingam L. and Messer LB. Early childhood caries: an update. Singapore Dent J.2004;26(1):2129

5. Agematsu H. Relationship between large tubulus and in human deciduous tooth. Bull Tokyo Dent Coll.2005; 46 (1-2): 7-15.

6. Mount GJ. Hume WR. Preservation and restoration of tooth structure. $2^{\text {nd }} e d$. Queensland. McIntyre, 2005.

7. Sondang P. Hamada T. Menuju gigi dan mulut sehat: pencegahan dan pemeliharaan. Medan: USU press. 2015.

8. Shirzard M. Taghdisi M. H. Dehdari T. Abolghasemi, J. Oral health education program among pre-school children: an application of healing-promoting schools approach. HPP J. 2016; 6(3): 164-70.

9. Blinkhorn F. Brown N. Freeman R. Humphris G. Martin A. Blinkhorn A. A phase ii clinical trial of a dental education program delivered by aboriginal health workers to prevent early childhood caries. BMC Public Health. 2012;12: 681; 2-8.

10. Sheiham A., Dental caries affects body weight, growth, and quality of life in preschool children. British Dental Journal, 2006, 201(10): 625-626.

11. Saidah ES. Pentingnya stimulasi mental dini. jurnal ilmiah pendidikan anak usia dini. 2003;1:50-55

12. Singhal DK, Acharya A, Thakur AS. Maternal knowledge, attitude and practice regarding oral helth of preschool children in Udupi taluk, Karnataka, India. J.Int Dent Med Res.2017;10(2):270-277

13. Kemenkes RI, Laporan nasional RIKESDAS 2018, Badan Pengembangan dan Penelitian Kesehatan, Kemenkes RI, 2018.

14. Rahina Y. Surwandi W. The Effect of drama and tooth brushing methods in dental caries of kindergarten children. TIIKG-Unhas. Makassar 5-7 April, 2018.

15. PBPDGI, Indonesian oral health survey implementation-national basic health research (RISKESDAS) 2018 : Buku survei kesehatan gigi dan mulut implementasinya pada Riskesdas 2018, Jakarta, PBPDGI, 2017.

16. Kemenkes RI, Infodatin: Pusat data dan informasi Kemenkes RI. Jakarta, DepKes RI, 2014.

17. Khanduri N, Singhal N, Mitra M, Rohatgi S. Knowledge, attitude and practice of parents toward their children's oral health: A questionnaire survey in Bhairahawa (Nepal). Int.J of Pedo Rehab. 2018. 2(7)

18. Lemos LV. Myaki SI. Walter LR. Zuanon AC. Oral health promotion in early childhood: age of joining preventive program and behavioral aspects. Einstein (Sao Paulo). 2014;12(1): 6-10.

19. Samad R. Qasih RN. Hastuty W. Parents myths regarding their children's teething in urban and rural Makassar City South Sulawesi, Indonesia. 2011;URI:http;//repository.unhas.ac.id/handle/12345 6789/369 down load 15.2.2018.

20. Kamil MA, El Ameen NM, Madkhaly SH, Alsyamarry TH, Hakami RU, Nassir EM, Knowledge and attitude of saudymothers towards health primary teeth, J Dent Oral Hyg. 2015, 7(7);107-112

21. Oliveira LB, Sheilham A, Bonecker M, Exploring the association of dental caries with social factors ant nutritional status in Brazilian preschool children, Eur J Oral Sci, 2008; 116(1);37-43

22. Mota A, Oswal KC, sajnani AK, Oral helth knowledge, attitude and approaches of pre-primary and primaru school teacher in Mumbai, India, Scientifica, 2016, 2016;5967427

23. Wiener, R.C. Crout, R.J. Wiener, M.A. toothpaste use by children, oral hygiene, and nutritional education: an assessment of parental performance. The J of Den Hyg. 2009;83(3).

24. Hooley M, Skouteris H, Boganin C, Satur J, Kilpatrick N. Parental influence and the development of dental caries in children age 0-6 years: A systematic review of review of the literature. J of den. 2012; 40:873-885 
25. Esan A. Folayan MO. Egbetade GO. Oyedele TA. Effect of a school-based oral health education programme on use of recommended oral self-care for reducing the risk of caries by children in Nigeria. Int J Paediatr Dent. 2015; 25(4): 282-90.

26. Felden CA. Giugliani ERI. Duncun BB. Dracler ML. Vitolo MR. Long-term effectiveness of a nutritional program in reducing early childhood caries: a randomized trial. Community Dent Oral Epidemiology 2010; 38:324-332

27. Almonaitiene R, Balciuniene I, Tulkaviene J. Factors influencing permanent tooth eruption. Stomatologija Baltic Dental and Maxillofacial J. 2010;(12):67-72.

28. Alvarez O J. Navia MJ. Nutritional status, tooth eruption, and dental caries. The American $\mathrm{J}$ of Clinical Nutrition. 1995; (49):417-26

29. Melo P, Fine C, Malone S, Frecken JE, Horn V. The effective of the brush day and night programme in improving children's toothbrushing knowledge and behaviour. Int Dent J. 2018.68(1): 7-16

30. Lee JW, Choi HN. Effect of repeated oral health education on the oral health of preschool childreen. J Dent Hyg Sci. 2017;17(5):423-432

31. Santos A, Nandanovsky P, Oliveira BH. A systematic review and meta-analysis of the effects of fluoride toothpaste on the prevention of dental caries in the primary teeth of preschool children. Commuity Dent Oral Epid. 2013; 41: 1-12

32. Narayan N. Knowledge and awareness regarding primary teeth and their Importance among parents in Chennai City, J. Pharm Sci \& Res. 2017;9(2):212-4

33. Case A, Paxson C, Parental behavior and child health. Health Aff (Millwood) 2002; 21(2):164-78

34. AAPD (American Academy of Pediatric Dentistry), Guideline on infant oral health care. AAPD Reference Manual. 2012-2013; 34 (6): 132-136.

35. Wennhall I, Matsson L. Schroder U, Twetman S, Outcome of an oral health outreach programme for preschool children in a low socioeconomic multicultural area. Int J of Pediatric dent. 2008; 18: 84-90.

36. Kemenkes RI, Buku panduan pelatihan kader kesehatan gigi dan mulut di masyarakat (UKGM), Jakarta: Dirjen Bina Usaha Kesehatan, 2012.
37. Spurr S. Bally J. Ogenchuk M., Integrating oral health into pediatric nursing practice: caring for kids where they live. $\mathrm{J}$ for Specialists in Pediatric Nursing, 2015; 20(2): 105-14.

38. Mahat G, Bowen F. Parental knowledge about urban preschool children's oral health risk. Pediatric Nursing. 2017;43(1):30-34

39. Edelstein BI. Disparities in oral health and acces in care. Finding of national surveys. Ambul Pediatr. 2002; $2: 141-7$

40. Naidu R. Nunn J. Forde M. Oral healthcare of preschool children in Trinidad: qualitative study of parents and caregivers. BMC oral health, 2012; $12: 27$

41. Kowash MB, Pinfield A, Smith J. Curzon EJ. Oral Health-educating mother with young children, British dent J. 2000; 188(4);199

42. Raj S. Goel S. Sharma VL Goel NK, Short-term impact of oral hygiene training package to Anganwadi wokers on improving oral hygiene of preschool children in North Indian City, 2013;13;67

43. Naidu R. Nunn J. Irwin J.D., The Effect of Motivational Interviewing on Oral Healthcare Knowledge, Attitude and Behavior of Parents and Caregivers of Preschool Children: An Exploratory Cluster Randomized Controlled Study. BMC Oral Health. 2015; 15:101.

44. Rompis C, Pangemanan D, Gunawan P, Hubungan tingkat pengetahuan ibu tentang kesehatan gigi anak dengan tingkat keparahan karies anak TK di kota Tahuna, J e-G, 2016; 4(1);46-52

45. Bahuguna R, Jain A, Khan SA, knowledge and attitudes of parents regarding child dental care in Indian population. Asian $\mathbf{J}$ of oral health and allied Sciences, 2011;1(1):9-12

46. Weinstein P. Harrison, R. and Benton T. Motivating Mother to Prevent Caries. JADA, 2006; 137: 789793.

47. Assery MK. Effectiveness of providing dental health education to mothers in controlling Dental disease in children. J of Int Oral Health. 2015;7(11):1-4 